\title{
Role of ultrasonography in determining the cricothyroid membrane localization in the predicted difficult airway
}

\author{
Demet Altun, M.D., ${ }^{1}$ Achmet Ali, M.D., ${ }^{1}$ Kemalettin Koltka, M.D., ${ }^{1}$ Mehmet Büget, M.D., ${ }^{1}$ \\ Mehmet Çelik, M.D., ${ }^{2}$ Can Doruk, M.D., ${ }^{2}$ Ali Emre Çamcı, M.D. ${ }^{1}$
}

${ }^{1}$ Department of Anesthesiology and Reanimation, İstanbul University İstanbul Faculty of Medicine, İstanbul-Turkey

${ }^{2}$ Department of Otolaryngology, Head and Neck Surgery İstanbul University İstanbul Faculty of Medicine, İstanbul-Turkey

\begin{abstract}
BACKGROUND: The aim of this study was to investigate the success rates of ultrasound (US) and palpation methods in identifying the cricothyroid membrane (CTM), and compare the results with the gold standard method-computed tomography (CT) scan.

METHODS: A total of 110 patients were included into the study. The midline was estimated by a single investigator using both the US and palpation methods from the prominence of the thyroid cartilage to the center of the sternal notch, and the distance was measured (in millimeters) between the two points: Point $A$ (the midpoint of CTM) and Point $B$ (the inferior process of thyroid cartilage). Furthermore, the distance between Point $A$ and Point $B$ was calculated using the CT images. Time taken to assess the CTM by using US and palpation methods were recorded. Moreover, difficulty in using the two methods was measured with the visual analog scale (VAS). In addition, demographic and morphometric characteristics of the patients were noted.

RESULTS: The CTM was detected accurately in 50 (45.5\%) patients with palpation and 82 (74.5\%) with US. In the Bland-Altman analysis, a better agreement was observed with US. The time to assess CTM was shorter with US than with palpation, $\mathrm{p}<0.00 \mathrm{I}$. The VAS scores for the palpation and US difficulty were $5.13 \pm \mathrm{I} . \mathrm{I}$ and $3.32 \pm 0.9(\mathrm{p}<0.00 \mathrm{I})$, respectively. While an increased neck circumference and thyromental distance were found to be independent risk factors for the success rates of determining the CTM by palpation, body mass index is an independent risk factor for US.
\end{abstract}

CONCLUSION: Localization of the CTM is more accurate and easier with US than palpation. Furthermore, the results gathered with US are in a closer range to CT scan.

Keywords: Airway management; cricoid cartilage; thyroid cartilage; ultrasound imaging.

\section{INTRODUCTION}

The cricothyroid membrane (CTM), located in the anterior neck between cricoid and thyroid cartilages, is the emergency cricothyroidotomy site of puncture. Emergency cricothyroidotomy, although rarely performed, is the "fail-safe" step in cases of "cannot intubate, cannot oxygenate" (CICO) scenarios, when all previous options for the noninvasive establishment of airway have failed (Difficult Airway Society, DAS). The $\mathrm{CICO}$ scenario is relevant to anesthesiologists as this situation is accountable in approximately $25 \%$ of anesthesi- a-related deaths. ${ }^{[1,2]}$ Yet, cricothyroidotomy performed in emergency situations has a high failure rate (up to $30 \%$ ), and it takes a longer period of time, which causes further problems in an already desaturated patient.

It is noteworthy that this failure is frequently associated with tube misplacement. ${ }^{[3]}$ Hence, a correct technique and an accurate identification of the precise localization of CTM before performing cricothyroidotomy are crucial to prevent further morbidity (laryngotracheal injury) and mortality (death). Thus, improving skills to locate this membrane is of

Cite this article as: Altun D, Ali A, Koltka K, Büget M, Çelik M, Doruk C, et al. Role of ultrasonography in determining the cricothyroid membrane localization in the predicted difficult airway. Ulus Travma Acil Cerrahi Derg 2019;25:355-360.

Address for correspondence: Demet Altun, M.D.

İstanbul Üniversitesi İstanbul Tıp Fakültesi, Anesteziyoloji ve Reanimasyon Anabilim Dalı, İstanbul, Turkey

Tel: +90 212 - 4142000 / 31742 E-mail: drdemetaltun@hotmail.com

Ulus Travma Acil Cerrahi Derg 2019;25(4):355-360 DOI: 10.14744/tjtes.2019.65250 Submitted: 29.1I.2018 Accepted: 08.03.2019 Online: 15.04.2019

Copyright 2019 Turkish Association of Trauma and Emergency Surgery 
utmost importance for anesthesiologists, otolaryngologists, and emergency physicians.

The traditional method to identify CTM is palpation. The palpation of CTM can be achieved externally without any incision. However, in some cases, it is not possible for physicians to palpate the membrane. The suggested line of action by the DAS 2015 guidelines is to make a vertical incision at the level of the cricoid cartilage and perform a finger dissection until the membrane is exposed. ${ }^{[4]}$ Previous studies have indicated that the success rates of palpation show great variations and are heavily affected by gender, body mass index (BMI), and position. ${ }^{[5,6]}$ The average success rate is $72 \%$ for non-obese and $39 \%$ for obese males, ${ }^{[5]}$ whereas it is $71 \%$ for non-obese ${ }^{[6]}$ and $39 \%$ for obese females. ${ }^{[7]}$

Ultrasound (US) has remarkably improved the success rate of the CTM identification (95\%-100\% $)^{[8,9]}$ and decreased the complication rates. ${ }^{[7]}$ However, the clinical efficacy of the US guidance to identify the CTM is unclear compared to computed tomography (CT), which is a commonly used radiological technique and allows an accurate identification of the airway structures. ${ }^{[10]}$

The aim of this prospective clinical study was to investigate the success rates of US and conventional finger palpation methods in identifying the cricothyroid membrane (CTM) and comparing the precision of identifying the CTM against the commonly used radiological technique-the CT scan. The time taken to assess CTM using the US and finger palpation methods and the difficulty of using these methods and factors associated with the success rates while determining the CTM localization were the secondary outcomes.

\section{MATERIALS AND METHODS}

\section{Study Population and Setting}

A clinical study approval was obtained from the Institutional Ethics Committee (2016/84). Patients aged 18-65 years who received general anesthesia for any kind of neck surgery and who had previous neck CT images present were screened during the 4-month period for this study. Written consent was obtained from the patients prior to surgery. Patients who could not lay in the supine position or keep their head in the neutral position and patients whose CT scans did not include CTM were excluded from the study.

After the premedication with oral midazolam at a dose 0.5 $\mathrm{mg} / \mathrm{kg}$, the patient was taken to the operating room, and standard monitoring (ECG, $\mathrm{SPO}_{2}$, and non-invasive arterial pressure) was applied. A standard anesthesia regimen was induced, and intubation was applied successfully to all patients.

\section{Data Collection}

Patients were placed in the supine position with the head in the neutral position.
One investigator (A.A.) was asked to identify the CTM by using both the finger palpation technique and US in the brightness (B) mode using a $12 \mathrm{MHz}$ linear probe (GE Healthcare LOGIQ e ultrasound), and to point out the margins of the CTM with a board marker. The assessment was performed by a single investigator who had experience in the managing of difficult airway and ultrasonographic evaluation of airway. A PowerPoint presentation of 20 minutes on the US airway anatomy and CTM detection was also used to revise the important points prior to initiating the study.

The midline was identified by drawing a line from the prominence of the thyroid cartilage to the center of the sternal notch, and all measurements and markings were performed at midline. The primary outcome was the distance measured in millimeters between the two points: Point $A$ (the midpoint of CTM) and Point B (the inferior process of the thyroid cartilage where the CTM attaches). The points were marked by the investigator using US or palpation (Fig. I). After each attempt, the accuracy of the estimate points of the investigator was also confirmed or refuted by an attending anesthesiologist experienced in airway ultrasonography (DA).

The distance between Point $A$ and Point $B$ was also calculated by using the CT images with the InSight Picture Archiving and Communication System in the midline sagittal plane by an experienced consultant radiologist.

The time required to assess the CTM by US was defined as the time from the first contact of the US probe with the skin to the marking of the CTM. In the case of palpation, it was defined as the time from the beginning of palpation of the skin to the marking of the CTM. The time measurements were reported.

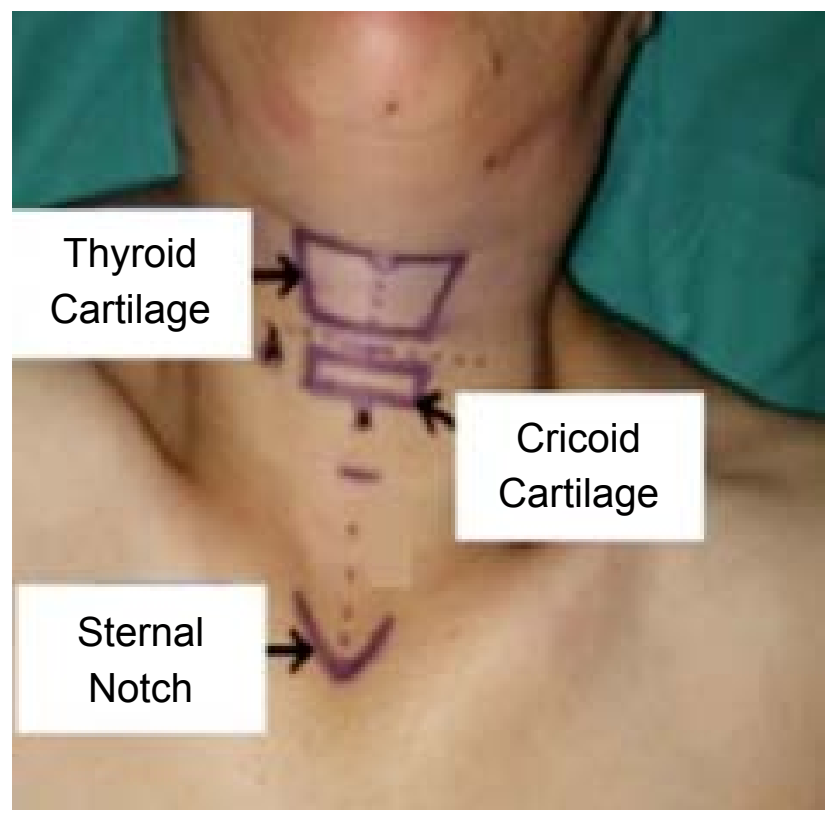

Figure 1. Image of landmarks of the thyroid cartilage, cricoid cartilage, and sternal notch marked on a female patient. 
The participating investigator was also asked to assess the ease of US and palpation method by using a $10 \mathrm{~cm}$ visual analog scoring (VAS) scale where 0 represented the easiest and 10 the most difficult. In addition, demographic data (age, gender, $\mathrm{BMI})$; the neck circumference $(\mathrm{cm}$; at the level of the thyroid cartilage); thyromental distance $(\mathrm{mm}$; the distance from the mentum to the thyroid notch); sternomental distance ( $\mathrm{mm}$; the distance from the suprasternal notch to the mentum); mouth opening (cm; inter-incisor distance-the distance between the upper and lower incisors); the Mallampati classification; ${ }^{[1]}$ and Cormach-Lehane scores ${ }^{[12]}$ were noted.

\section{Statistical Analysis}

Continuous data were presented as the mean \pm standard deviation (SD), median (min-maximum), or the number of patients (\% incidence). The Mann-Whitney $U$ test was used for the comparison of quantitative variants. Qualitative variants were compared using the chi-square test or the Fischer exact test, as appropriate. A p-value $<0.05$ was considered statistically significant.

The Bland-Altman analysis was used to further assess the similarity of methods, and the range of agreement was defined as the mean bias and $95 \%$ confidence interval $(\mathrm{Cl}) . A$ binary logistic regression analysis was used for the risk analysis for gender, BMI, thyromental distance, sternomental distance, neck circumference, mouth opening, the Mallampati classification, and the Cormach-Lehane scores. The odds ratio $(\mathrm{OR})$ and $95 \% \mathrm{Cl}$ were listed for detected independent risk factors.

Data were analyzed using the MedCalc Statistical Software version 12.7.7 (MedCalc Software bvba, Ostend, Belgium; www.medcalc.org; 2013).

\section{Sample Size Calculation}

The sample size was calculated according to the primary outcome. Bland and Altman ${ }^{[13]}$ recommended that at least 100 patients be included in the analysis, so that a calculation can be achieved with the $95 \% \mathrm{Cl} \pm 0.34 \mathrm{~s}$, which is the SD of the differences between measurements by the two methods. The required numbers of screened volunteers were achieved at the end of the 4 month.

\section{RESULTS}

In this study, II7 patients undergoing neck surgery were screened between February and May 2016. Two patients who refused to participate in the study, 2 patients who could not lay down in a neutral position due to mild chronic obstructive pulmonary disease, and 3 patients who did not have a preoperative CT scan documenting CTM were excluded from the study. Data from the remaining I 10 patients were included in the statistical analysis (Fig. 2). The demographic and morphometric characteristics of the patients are presented in Table I.
The accuracy of detecting CTM with US (in 82 patients [74.5 $\%]$ ) was significantly more successful than with palpation (in 50 patients $[45.5 \%])(p<0.05)$ (Table 2$)$.

In the Bland-Altman analysis, a bias of $2.79 \mathrm{~mm}$ was detected between palpation and CT (95\% limits of agreement, $0.55-$ $5.03 \mathrm{~mm}$ ) (Fig. 3a).

In the Bland-Altman analysis, a bias of $0.73 \mathrm{~mm}$ was detected between US and CT (95\% limits of agreement, 0.58-2.04 $\mathrm{mm}$ ] (Fig. 3b).

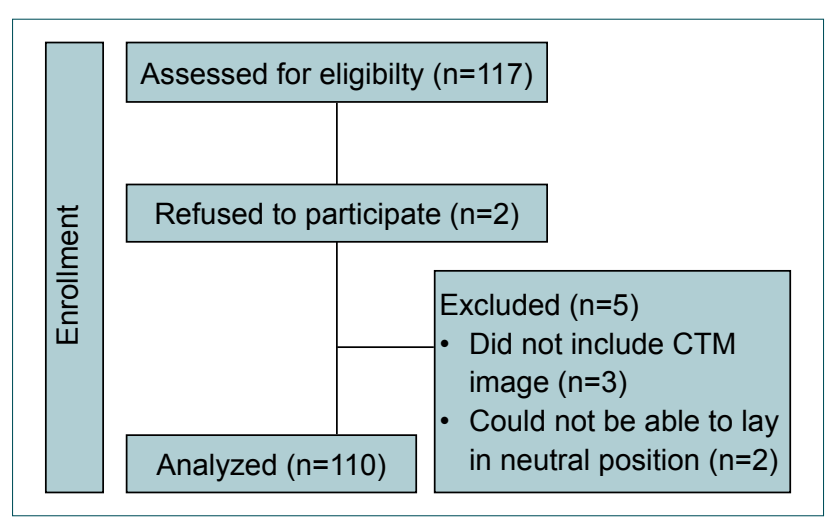

Figure 2. Study flow diagram.

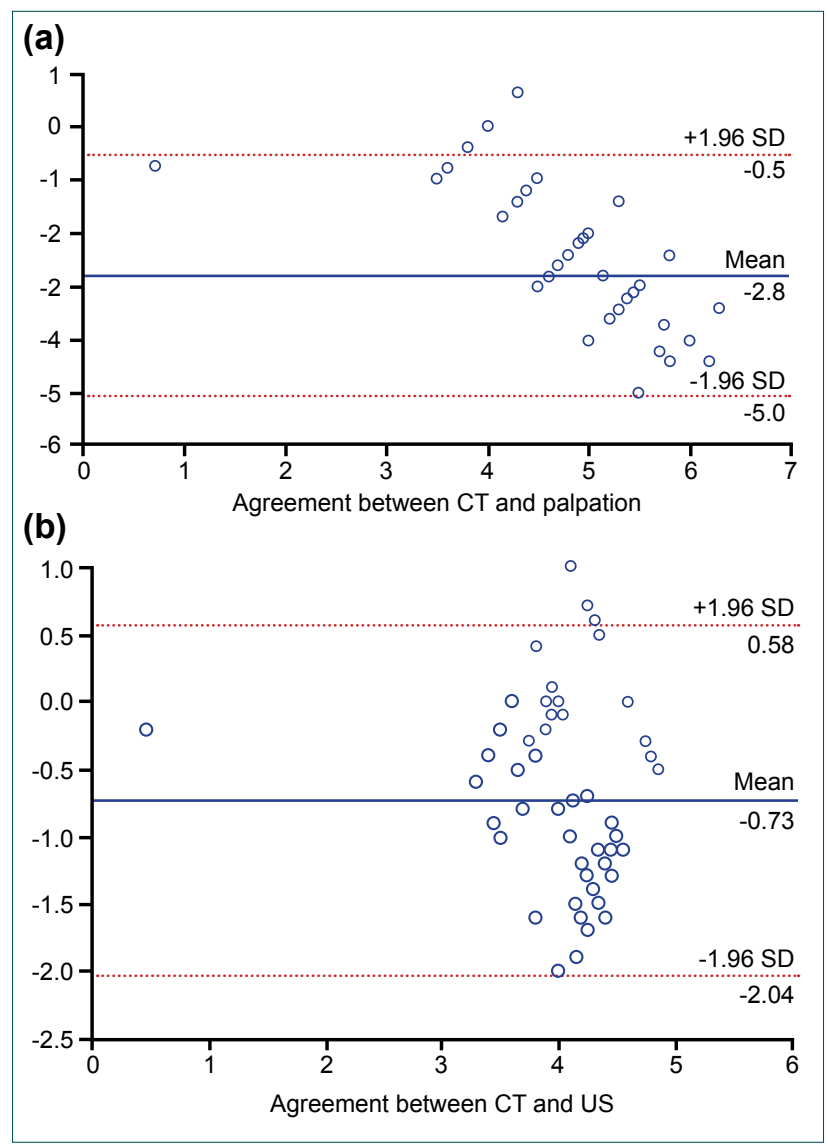

Figure 3. Agreement between different methods. (a) Agreement between CT and palpation. (b) Agreement between CT and US. 
Table I. Demographic and morphometric characteristics of the patients

\begin{tabular}{lc}
\hline Variable & Data $(\mathbf{n}=1 \mathrm{l}$ ) \\
\hline Age (years) & $63.3 \pm 10.25$ \\
Gender & \\
$\quad$ Male & $80(72.7 \%)$ \\
$\quad$ Female & $30(27.3 \%)$ \\
Body mass index $\left(\mathrm{kg} / \mathrm{m}^{2}\right)$ & $28.2 \pm 3.66$ \\
Neck circumference $(\mathrm{cm})$ & $42 \pm 3.76$ \\
Thyromental distance $(\mathrm{cm})$ & $6.08 \pm 0.14$ \\
Sternomental distance $(\mathrm{cm})$ & $1 \mathrm{I} .4 \pm 0.23$ \\
Mouth opening $(\mathrm{cm})$ & $5.2 \pm 0.07$ \\
Mallampati $(\mathrm{I} / 2 / 3 / 4)$ & $2.3 \pm 0.62$ \\
Cormach-Lehane score $(\mathrm{I} / 2 / 3 / 4)$ & $2.1 \pm 0.6 \mathrm{I}$ \\
\hline
\end{tabular}

Data are given as mean \pm standard deviation (SD) or number of patients (\% incidence).

Table 2. Accuracy rate and time taken to assess the CTM and VAS difficulty scores

\begin{tabular}{lccc}
\hline & $\begin{array}{c}\text { Palpation } \\
(\mathbf{n}=110)\end{array}$ & $\begin{array}{c}\text { US } \\
(\mathbf{n}=110)\end{array}$ & p \\
\hline $\begin{array}{l}\text { Accuracy rate (\%) } \\
\begin{array}{l}\text { Time taken to assess } \\
\text { the CTM (seconds) }\end{array}\end{array}$ & $50(45.5)$ & $82(74.5)$ & $<0.05$ \\
$\begin{array}{l}\text { VAS difficulty score } \\
(0-10 \mathrm{~cm})\end{array}$ & $5.1 \pm 1.1$ & $3.32 \pm 0.9$ & $<0.001$ \\
\hline
\end{tabular}

CTM: Cricothyroid membrane; VAS: Visual Analog Scale; US: Ultrasound. Data are presented as mean \pm standard deviation (SD) or number of the patients (\% percentage).

Table 3. Measurement of CTM localization by palpation, US, and $\mathrm{CT}$

\begin{tabular}{lccc}
\hline & $\begin{array}{c}\text { Measurement } \\
\text { by palpation } \\
(\mathbf{m m}) \\
(\mathbf{n}=I 10)\end{array}$ & $\begin{array}{c}\text { Measurement } \\
\text { by US } \\
(\mathbf{m m}) \\
(\mathbf{n}=I 10)\end{array}$ & $\begin{array}{c}\text { Measurement } \\
\text { by CT } \\
(\mathbf{m m}) \\
(\mathbf{n}=I 10)\end{array}$ \\
\hline $\begin{array}{l}\text { Mean } \pm S D \\
\text { Median }\end{array}$ & $6.49 \pm 1.2$ & $4.04 \pm 0.7$ & $3.7 I \pm 0.47$ \\
$($ min-max $)$ & $7(I . I I-8.4)$ & $4.6(0.56-5.2)$ & $3.6(0.35-4.6)$ \\
\hline
\end{tabular}

CTM: Cricothyroid membrane; US: Ultrasound; CT: Computed tomography; SD: Standard deviation. Data are presented as mean \pm standard deviation (SD) or median (min-max).

The distance between Points $A$ and $B$ was calculated as $6.49 \pm 1.2 \mathrm{~mm}$ by palpation and $4.04 \pm 0.7 \mathrm{~mm}$ by US, while this distance was calculated as $3.7 \mathrm{I} \pm 0.47 \mathrm{~mm}$ by CT (Table 3 ).
The mean time for the assessment of CTM by palpation and US was $54.2 \pm 10.4$ seconds $(95 \% \mathrm{Cl} 52.2-56.1$ seconds) and $29.0 \pm 5.03$ seconds ( $95 \% \mathrm{Cl} 28.0-29.9$ seconds), respectively, $\mathrm{P}<0.00 \mathrm{I}$ (Table 2). The duration for detecting the localization of the CTM by palpation was significantly longer than with US.

The VAS scores for palpation and US difficulty were $5.13 \pm \mathrm{I}$. I and $3.32 \pm 0.9 \mathrm{~cm}$, respectively. Thus, to find the CTM by palpation is significantly more difficult than with US $(p<0.001)$ (Table 2).

Binary logistic regression was later performed for the following factors: gender, BMI, the thyromental distance, sternomental distance, neck circumference, mouth opening, the Mallampati classification, and the Cormach-Lehane scores. Of these, while an increased neck circumference $(p=0.010$; OR, 2.099; 95\% Cl, I.193-3.693) and thyromental distance ( $p=0.004 ;$ OR, $0.076 ; 95 \% \mathrm{Cl}, 0.013-0.443$ ) were found to be independent risk factors for the success rates of determining CTM by palpation, BMI was the independent risk factor for the success rates of determining CTM by US $(p<0.002$; OR, 0.369; 95\% Cl, 0.195-0. 70I).

\section{DISCUSSION}

This study was conceptualized to determine the success rates of palpation and US to localize CTM, and to compare the results with $\mathrm{CT}$, which is the most commonly used radiological technique in the upper airway evaluation. According to our study results, an accurate localization of CTM was more unsuccessful when conventional palpation (45.4\%) was used than US (74.5\%), and US has improved the success rates. Similar results were reported in the literature in previous studies. ${ }^{[14,15]}$ Interestingly, the palpation method has only been compared to US, which is also inadequate in defining CTM borders. CT is expected to be more precise than the US and palpation method, because CT imaging is considered to be an omnipresent feature reflecting the precise anatomy of CTM. [10] Therefore, this study compares and validates the palpation and US method against the commonly used technique, i.e., CT scan, for the first time to the best of our knowledge.

According to the results of our study, the average distance between Points $A$ and $B$ was measured as $6.49 \pm 1.2$ by palpation and $4.04 \pm 0.7$ by US (millimeters \pm SD). The study of Aslani et al. ${ }^{[16]}$ indicated that CTM should be within $5 \mathrm{~mm}$ of the midpoint. Since CTM is a very small, errors $>5 \mathrm{~mm}$ might cause major complications, such as a cricothyroidotomy failure, cricoid/thyroid cartilage puncture, or soft tissue damage. Although the measurements taken by US are within these ranges, palpation results exceed this cut-off point.

The Bland-Altman analysis of our results indicate that the US results are closer to $C T$ than palpation, which indicates that the CTM localization can be done more precisely by US. 
Despite advanced airway management options, cricothyroidotomy is considered to be the last but crucial method for an emergency airway access in difficult airway management. Traditional methods to identify the surface landmarks of CTM rely on inspection and palpation, but the CTM localization is often difficult or impossible with these methods. ${ }^{[5,17]}$ Hence, clinicians are often mistaken, which may lead to serious complications that might cause prolonging of the hypoxia time or chronic airway problems. In our study, a statistically significant relation between an increased neck circumference and thyromental distance was found with the failure of CTM palpation. In the study of Aslani et al., ${ }^{[16]}$ a statistically significant relation between the palpation failure and weight, BMI, and neck circumference was observed. Although our results are consistent with the literature, they do not confirm the correlation between $\mathrm{BMI}$ and the male gender with palpation failure, which should be re-evaluated with a higher number of subjects.

US has been shown as a reliable, noninvasive method in the evaluation of the airway and determination of the CTM, and several studies have investigated the accuracy of the USguided localization of the CTM over classic landmark techniques. ${ }^{[6,14,15,18-20]}$

The ease of US use is significantly correlated more strongly with a higher BMI, the male gender, an increased neck circumference, thyro-mental distance, and sterno-mental distance. However, the multivariate analysis results show that only a higher BMI reached statistical significance. You-Ten et al. ${ }^{[6]}$ reported that a high BMI (defined as obesity, BMI $\geq 30 \mathrm{~kg} . \mathrm{m}^{2}$ ) was significantly correlated with an increased inaccuracy in CTM locating.

Cricothyroidotomy is performed as an emergency method. This increases the significance of the duration of the procedure greatly, which is directly proportional to the hypoxia period. Our results show that time consumed to localize CTM by palpation is significantly longer than in US. Of note, our time for the US measurement only accounts for the time when the probe is placed on the anterior neck. However, the transfer of the machine to the operating room and preparation may also cause the loss of time in a critical situation. As presented in previous studies according to the DAS, the recommended mean time for the assessment of CTM was 40 seconds or less for airway rescue..$^{[14,21,22]}$ To achieve such a critical timing, DAS guidelines also recommend that the identification of trachea and CTM should be done during the preoperative evaluation, and the examination of the patient should be performed with US if the landmarks are not clear. ${ }^{[4]}$

The most important limitation to our study is that the investigator performed palpation and US evaluation under elective conditions, when the patient has already been intubated. This condition might have positively affected the localization time and lower the VAS scores. On the other hand, performing this study in real emergency scenarios would not be ethical.
In emergency conditions, US may lengthen the time taken to identify the CTM and to complete the procedure.

The other limitation of the study is that, although our staff anesthesiologists received a training for US evaluation for airway during their residency, this training has not been evaluated. Although a revision for the study was completed prior to patient inclusion, an experience in ultrasonographic assessment is limited. This condition might negatively alter our localization time scores and might cause higher VAS scores. However, the fact that US is related to consistent evaluation times and a better accuracy, even in limited experience, is important.

\section{Conclusion}

In conclusion, our study differs from the aforementioned studies, as the US method has not been validated against the commonly used technique, which is a CT scan, to determine the precision of identifying the midpoint of CTM. Our results indicated that the CTM localization is more accurate and easier when using US than by palpation; however, obesity might aggressively affect the US airway evaluation. Furthermore, the results gathered with US are in close range with CT scan. Lastly, to increase the success rate and decrease the complication rate while performing cricothyroidotomy, the US use may prove to be an important method, but further research on this clinical application should be performed.

\section{Institutional Ethics Committee Approval: 2016/84 Government Ethics Committee Chair: Prof. Dr. A. Yağız Üresin.}

Funding: This research was carried out without funding.

\section{Conflict of interest: None declared.}

\section{REFERENCES}

1. Cook TM, Woodall N, Frerk C; Fourth National Audit Project. Major complications of airway management in the UK: results of the Fourth National Audit Project of the Royal College of Anaesthetists and the Difficult Airway Society. Part 1: anaesthesia. Br J Anaesth 2011;106:61731. [CrossRef]

2. Langvad S, Hyldmo PK, Nakstad AR, Vist GE, Sandberg M. Emergency cricothyrotomy-a systematic review. Scand J Trauma Resusc Emerg Med 2013;21:43. [CrossRef]

3. Erlandson MJ, Clinton JE, Ruiz E, Cohen J. Cricothyrotomy in the emergency department revisited. J Emerg Med 1989;7:115-8. [CrossRef]

4. Frerk C, Mitchell VS, McNarry AF, Mendonca C, Bhagrath R, Patel A, et al. Difficult Airway Society 2015 guidelines for management of unanticipated difficult intubation in adults. Br J Anaesth 2015;115:827-48.

5. Lamb A, Zhang J, Hung O, Flemming B, Mullen T, Bissell MB, et al. Accuracy of identifying the cricothyroid membrane by anesthesia trainees and staff in a Canadian institution. Can J Anaesth 2015;62:495-503.

6. You-Ten KE, Desai D, Postonogova T, Siddiqui N. Accuracy of conventional digital palpation and ultrasound of the cricothyroid membrane in obese women in labour. Anaesthesia 2015;70:1230-4. [CrossRef]

7. Siddiqui N, Arzola C, Friedman Z, Guerina L, You-Ten KE. Ultra- 
sound Improves Cricothyrotomy Success in Cadavers with Poorly Defined Neck Anatomy: A Randomized Control Trial. Anesthesiology 2015;123:1033-41. [CrossRef]

8. Curtis K, Ahern M, Dawson M, Mallin M. Ultrasound-guided, Bougieassisted cricothyroidotomy: a description of a novel technique in cadaveric models. Acad Emerg Med 2012;19:876-9. [CrossRef]

9. Tsui B, Ip V, Walji A. Airway sonography in live models and cadavers. J Ultrasound Med 2013;32:1049-58. [CrossRef]

10. Nutbeam T, Clarke R, Luff T, Enki D, Gay D. The height of the cricothyroid membrane on computed tomography scans in trauma patients. Anaesthesia 2017;72:987-92. [CrossRef]

11. Mallampati SR, Gatt SP, Gugino LD, Desai SP, Waraksa B, Freiberger D, et al. A clinical sign to predict difficult tracheal intubation: a prospective study. Can Anaesth Soc J 1985;32:429-34. [CrossRef]

12. Cormack RS, Lehane J. Difficult tracheal intubation in obstetrics. Anaesthesia 1984;39:1105-11. [CrossRef]

13. How can I decide the sample size for a study of agreement between two methods of measurement? Available at: https://www-users.york.ac.uk/ $\sim$ mb55/meas/sizemeth.htm. Accessed July 2, 2019.

14. Nicholls SE, Sweeney TW, Ferre RM, Strout TD. Bedside sonography by emergency physicians for the rapid identification of landmarks relevant to cricothyrotomy. Am J Emerg Med 2008;26:852-6. [CrossRef]

15. Kristensen MS, Teoh WH, Rudolph SS, Tvede MF, Hesselfeldt R, Børglum J, et al. Structured approach to ultrasound-guided identification of the cricothyroid membrane: a randomized comparison with the palpation method in the morbidly obese. Br J Anaesth 2015;114:1003-4. [CrossRef]

16. Aslani A, Ng SC, Hurley M, McCarthy KF, McNicholas M, McCaul CL. Accuracy of identification of the cricothyroid membrane in female subjects using palpation: an observational study. Anesth Analg 2012;114:987-92. [CrossRef]

17. Elliott DS, Baker PA, Scott MR, Birch CW, Thompson JM. Accuracy of surface landmark identification for cannula cricothyroidotomy. Anaesthesia 2010;65:889-94. [CrossRef]

18. Yildız G, Göksu E, Şenfer A, Kaplan A. Comparison of ultrasonography and surface landmarks in detecting the localization for cricothyroidotomy. Am J Emerg Med 2016;34:254-6. [CrossRef]

19. Siddiqui N, Yu E, Boulis S, You-Ten KE. Ultrasound Is Superior to Palpation in Identifying the CricothyroidMembrane in Subjects with Poorly Defined Neck Landmarks: A RandomizedClinical Trial. Anesthesiology 2018;129:1132-9. [CrossRef]

20. You-Ten KE, Wong DT, Ye XY, Arzola C, Zand A, Siddiqui N. Practice of Ultrasound-Guided Palpation of Neck Landmarks Improves Accuracy of External Palpation of the Cricothyroid Membrane. Anesth Analg 2018;127:1377-82. [CrossRef]

21. Dinsmore J, Heard AM, Green RJ. The use of ultrasound to guide timecritical cannula tracheotomy when anterior neck airway anatomy is unidentifiable. Eur J Anaesthesiol 2011;28:506-10. [CrossRef]

22. Henderson JJ, Popat MT, Latto IP, Pearce AC; Difficult Airway Society. Difficult Airway Society guidelines for management of the unanticipated difficult intubation. Anaesthesia 2004;59:675-94. [CrossRef]

\section{ORIJINAL ÇALIŞMA - ÖZET}

\section{Öngörülen zor havayolunda krikotiroit membran lokalizasyonunun belirlenmesinde ultrasonografinin rolü}

\section{Dr. Demet Altun, ${ }^{1}$ Dr. Achmet Ali, ${ }^{1}$ Dr. Kemalettin Koltka, ${ }^{1}$ Dr. Mehmet Buget, ${ }^{1}$ Dr. Mehmet Çelik, ${ }^{2}$ Dr. Can Doruk, ${ }^{2}$ Dr. Ali Emre Çamcı ${ }^{1}$}

${ }^{1}$ İstanbul Üniversitesi İstanbul Tıp Fakültesi, Anesteziyoloji ve Reanimasyon Anabilim Dalı, İstanbul ${ }^{2}$ İstanbul Üniversitesi İstanbul Tıp Fakültesi, Kulak Burun Boğaz Anabilim Dalı, İstanbul

AMAÇ: Bu çalışmanın amacı, ultrason (US) ve elle muayene yöntemlerinin başarı oranlarını araştırmak ve bilgisayarlı tomografiye (BT) karşı US ile elle muayenenin kıyaslanarak krikotiroid membranın (KTM) tanımlamak.

GEREÇ VE YÖNTEM: Çalışmaya II 0 hasta alındı. Tiroit kartilajın çıııntısından sternal çentiğin ortasına kadar düzlemde orta hat belirlendikten sonra, iki nokta arasındaki mesafe (milimetre) ölçüldü. A noktası-KTM'nin orta noktası ile B noktası-tiroit kartilajın inferiyor kısmı arasındaki mesafe (milimetre) US ve elle muayene ile tek bir araştırmacı tarafından işaretlenerek ölçüldü. Ayrıca A noktası ile B noktası arasındaki mesafe BT kullanılarak hesaplandı. US ve elle muayene ile KTM'in belirlenmesi için geçen süre ve VAS skoru kullanılarak her iki yöntemin kolaylı̆ı kaydedildi. Ek olarak hastaların demografik ve morfometrik karakteristikleri not edildi.

BULGULAR: Krikotiroit membran elle muayene ile 50 hastada (\%45.5) ve US ile 82 (\%74.5) hastada doğru olarak saptandı. Blant-Altman analizine göre US ile elle muayeneye göre daha iyi uyum gözlendi. KTM yerinin belirlenmesi için geçen süre US ile elle muayeneden daha kısa idi $(p<0.00 \mathrm{I})$. VAS değerleri elle muayene ve US ile sırasıyla 5.13 I. I, $3.32 \pm 0.9$ bulundu $(p<0.001)$. Artan boyun kalınlı̆ı ve tiromental mesafe elle muayene başarısını etkileyen risk faktörü olarak saptanırken US için risk faktörü olarak vücut kitle indeksi (VKi) bulundu.

TARTIŞMA: Krikotiroit membranın lokalizasyonu US ile elle muayeneden daha doğru ve kolay saptanmıştır. Ayrıca US ile bulunan sonuçlar BT'ye daha yakın bulunmuştur.

Anahtar sözcükler: Havayolu yönetimi; krikotiroit kıkırdak; tiroit kıkırdak; ultrason görüntüleme.

Ulus Travma Acil Cerrahi Derg 2019;25(4):355-360 doi: 10.14744/tjtes.2019.65250 